\title{
Differential feeding strategies in phyllidiid nudibranchs on coral reefs at Halmahera, northern Moluccas
}

Received: 16 September 2010/ Accepted: 16 November 2010/Published online: 5 December 2010

(C) The Author(s) 2010. This article is published with open access at Springerlink.com

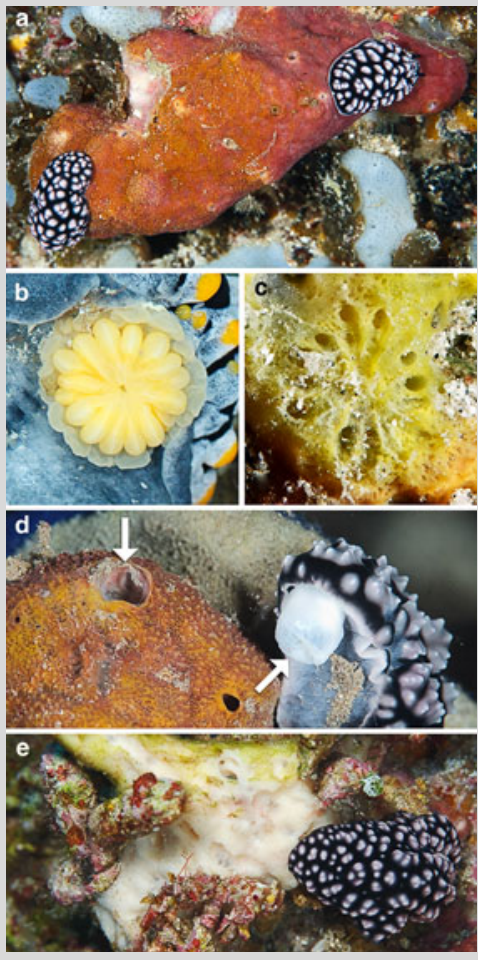

Fig. 1 a Individuals of Phyllidiella nigra (left) and Phyllidiella pustulosa (right) on the sponge Axinyssa aff. variabilis b Everted pharyngeal bulb of a Phyllidia varicosa. $\mathbf{c}$ Feeding mark in an Axinyssa aff. variabilis made by a $P$. varicosa. d Partly everted pharyngeal bulb of $P$. pustulosa (right arrow) that was extracted from a hole in an Axinyssa aff. variabilis (left arrow). e $P$. nigra individual feeding on an Axinyssa aff. variabilis
Sponges frequently produce toxic secondary metabolites, especially in tropical coral reefs. These metabolites are thought to have evolved as a chemically mediated defence mechanism and are highly effective against potential predators (Proksch 1994). Nudibranchs of the family Phyllidiidae feed on sponges of the order Halichondrida and exploit this adaptation: they selectively sequester the toxins and employ them for their own protection (RitsonWilliams and Paul 2007; Cimino and Ghiselin 2009). Other than most dorid nudibranchs, phyllidiids lack radulae and jaws. Rather, they are specialized in suctorial feeding. Their feeding apparatus consists of a small mouth followed by an inflated part of the pharynx known as the pharyngeal bulb, which contains secretory glands and can be everted (Fig. 1b, d), presumably for external digestion (Brunckhorst 1993).

During a biodiversity survey off West Halmahera (northern Moluccas) in 2009, we recorded seven phyllidiid species on six halichondrid species. Sponges were identified by the second author (NJdV). Vouchers are deposited in NCB Naturalis. Phyllidia varicosa, Phyllidiella pustulosa, and Phyllidiella nigra fed almost exclusively on the same sponge host, Axinyssa aff. variabilis (Fig. 1a), however, using different feeding techniques. $P$. varicosa feeds superficially, consuming little more than its host's skin, often leaving a pattern of multiple discoloured, rosette-shaped marks (Fig. 1c). In contrast, $P$. pustulosa inserts its exceptionally large pharyngeal bulb deep into the host sponge, frequently creating a narrow hole as deep as half its own length (Fig. 1d). Finally, $P$. nigra, which has a pharyngeal bulb similar to that of $P$. pustulosa, yet not quite as large, appears to consume consecutive chunks of tissue from the host's surface; in one instance, little of the exposed surface was left untouched (Fig. 1e). Dissection of two specimens of each species revealed a significant amount of whole spicules belonging to Axinyssa aff. variabilis in the digestive tracts of $P$. nigra and $P$. pustulosa, but not in $P$. varicosa.

In conclusion, $P$. varicosa, $P$. pustulosa, and $P$. nigra differ in the way they exploit their mutual host, and this difference may facilitate their coexistence in species-rich coral reefs.

Acknowledgments The survey was sponsored by the Research Centre for Oceanography, Indonesian Institute of Sciences (PPO-LIPI), and funded by the J. J. ter Pelkwijk Fund, the Martin Foundation, and the A.M. Buitendijk Fund. The research permit was issued by the Indonesian State Ministry of Research and Technology (RISTEK).

Open Access This article is distributed under the terms of the Creative Commons Attribution Noncommercial License which permits any noncommercial use, distribution, and reproduction in any medium, provided the original author(s) and source are credited.

References

Brunckhorst DJ (1993) The systematics and phylogeny of phyllidiid nudibranchs (Doridoidea). Rec Aust Mus Suppl 16:1-107 Cimino G, Ghiselin MT (2009) Chemical defense and the evolution of opisthobranch gastropods. Proc Calif Acad Sci 60:175-422

Proksch P (1994) Defensive roles for secondary metabolites from marine sponges and sponge-feeding nudibranchs. Toxicon 32:639-655 Ritson-Williams R, Paul VJ (2007) Marine benthic invertebrates use multimodal cues for defense against reef fish. Mar Ecol Prog Ser 340:29-39

J. van Alphen · N. J. de Voogd (凹) - B. W. Hoeksema

Netherlands Centre for Biodiversity Naturalis, P.O. Box 9517, 2300 RA Leiden, The Netherlands

e-mail: Nicole.devoogd@ncbnaturalis.nl

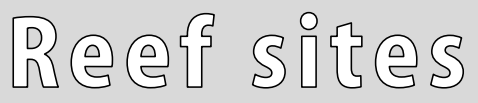

Coral Reefs (2011) 30:59

DOI $10.1007 / \mathrm{s} 00338-010-0698-y$ 